\title{
Essentialism in Spanish parents' descriptions of their transnationally adopted teenagers
}

\author{
Tomasa Báñez Tello - Universitat de Barcelona1
}

DOI: https://doi.org/10.5565/rev/periferia.611

\begin{abstract}
This preliminary qualitative study of 24 adoptive families in Catalonia, Spain asks how adoptive parents of teens describe the things they dislike about their children. This question matters because prior research shows that parents' views of their children can affect their parenting style and their relationships with their children. I show that in describing their dislikes, parents draw on essentialist beliefs about their children's culture of origin and about their personality traits. My analysis inspires questions about the possible relationship between essentialist parental beliefs and parenting practice, in both adoptive families and families more broadly. This is of particular relevance in the current moment, in which childrearing is influenced by neoliberal values that emphasize the social success of children and teens as future citizens and hold parents responsible for this outcome (Geinger et al., 2014). The research can also inform family and professional practices and public policies related to adoption.
\end{abstract}

Keywords: Transnational adoption, teenagers, essentialism, parents, Spain

Resumen. Narrativas esencialistas de padres que adoptan adolescentes en el campo trasnacional.

Este estudio preliminar cualitativo de 24 familias adoptivas en Cataluña, España analiza cómo los padres adoptivos de adolescentes describen las cosas que les desagradan de sus hijos. Esta cuestión es importante porque las investigaciones previas muestran que las opiniones de los padres sobre sus hijos pueden afectar su estilo de crianza y sus relaciones con ellos. El análisis muestra como al describir las cosas que nos les gustan de sus hijos, los padres recurren a creencias esencialistas sobre la cultura de origen de sus hijos y sobre sus rasgos de personalidad. Mi análisis plantea interrogantes sobre la posible relación entre las creencias esencialistas de los padres y la práctica de la crianza de los hijos, tanto en las familias adoptivas como en las familias en general. Esto es de particular relevancia en el momento actual, en el que la crianza de los hijos está influenciada por valores neoliberales que enfatizan el éxito social de los niños y adolescentes como futuros ciudadanos, responsabilizando a los padres por este resultado (Geinger et al., 2014). La investigación también puede orientar las prácticas familiares y profesionales y las políticas públicas relacionadas con la adopción.

Palabras clave: Adopción transnacional, adolescentes, esencialismo, padres,

${ }^{1}$ Enviar correspondencia a: Tomasa Báñez Tello: tomasabanez@ub.edu 
Tomasa Báñez Tello, Essentialism in Spanish parents' descriptions of their transnationally adopted teenagers, perifèria 22(2), diciembre 2017

revistes.uab.cat/periferia

España

\section{Introduction}

In this article I asked how parents of transnationally adopted teens describe the things they dislike about their children. This question matters because research suggests that parents' views of their children can affect their parenting and their family relationships (Dix and Grusec, 1985; Dix and Lochman, 1990; Snyder et al., 2005). Adoptive families are particularly interesting in this regard because they face additional pressures beyond the challenges of parenting in general, as described below. My analysis shows that some parents point to their children's supposedly inherent personal and cultural traits-or essences-as the root causes of these troubling behaviors.

Cultural essentialism-or the idea that people from a certain culture have certain predetermined traits-and its use by adoptive families, especially transnationally adopted families, has been analyzed for its troubling consequences for identity construction among adopted children and the creation, dissemination and maintenance of stereotypes and discrimination (Anzil, 2013; De Graeve and Longman, 2013; De Graeve, 2014; Lind, 2012; Howell, 2003, 2009; Hübinette and Andersson, 2012; San Román and Marre, 2013). Another line of research analyzes the consequences of personal essentialism-the belief that individuals have fixed personalities-on childrearing practices and outcomes (Dix and Grusec, 1985; Dix, and Lochman, 1990; Snyder et al., 2005).

On the one hand, both forms of essentialism may protect parents from feelings of responsibility and blame, which are the burden of parenting in the current neoliberal era (Geinger et al. 2014; Wall, 2010). On the other hand, to the extent that parents locate the causes of their children's troubling behavior in unchangeable "essences," they may lose a sense of agency-the conviction that their own behavior can have a positive effect on family outcomes. In addition to raising this paradox, the results of this analysis can orient family and professional practices and public policies, of particular relevance in the current moment in which children adopted at the peak of transnational adoption in Spain are reaching adolescence. 
Tomasa Báñez Tello, Essentialism in Spanish parents' descriptions of their transnationally adopted teenagers, perifèria 22(2), diciembre 2017

revistes.uab.cat/periferia

\section{Transnational adoption in Spain}

According to information recorded by the administration in the files of adoptive families, transnational adoption in Spain began in the 1990s and reached its peak in 2004, when there were 5.541 transnational adoptions. At that time, it was the second country worldwide in number of transnational adoptions (Selman, 2009). In 2014, Spain saw only $824^{2}$ transnational adoptions (INE, 2016), of which $180^{3}(21 \%)$ occurred in Catalonia. This boom in adoption occurred as an optimist-idealist understanding of adoption emerged in Spain, according to which love and the desire to form a family are understood to suffice for an adoption to succeed (Berástegui, 2007; Hoksbergen 1991). As has happened internationally with the exception of Italy (Selman, 2012), transnational adoption rates have fallen dramatically in Spain.

According to San Román (2013), beginning in 2008, a pathologizing view of adoption began to emerge in Spain. It characterizes adoption as necessarily involving "abandonment" and as generating a "primal wound". San Román points out that there is an advantage for adoptive parents in taking this view:

It allows them to face questions and doubts about the adoption and/or their children's potential problems as something whose genesis is totally unrelated to them. Rather, it is seen as an inevitable consequence of their "origins," an interpretation that allows them to take the role of rescuers or "therapeutic families" (p. 8)

This view of adoption is widespread as an explanation for the increase in family conflicts as adopted children enter adolescence and it is being widely disseminated through self-help books written in Spain or translated into Spanish and television programs, such as the documentary Adoption: 18 Years Later, which aired on Catalan

\footnotetext{
2 The main countries of origin for these adoptions were China (229), Russia (161), Vietnam (88), Philippines (82) and Ethiopia (79) (INE, 2016).

3 Coming mostly from Russia (38), Vietnam (26), China (19), Ethiopia (16) and Bulgaria (14) (IDESCAT, 2016).
} 
Tomasa Báñez Tello, Essentialism in Spanish parents' descriptions of their transnationally adopted teenagers, perifèria 22(2), diciembre 2017

\section{revistes.uab.cat/periferia}

television in May 2014. ${ }^{4}$ The show discussed the problems of adopted young people related to adolescence and their experience of "abandonment": "Having reached adulthood, they have left behind adolescence-one of the most difficult stages in the formation of the personality-and have become conscious of their circumstances and the factors that led to their abandonment". My previous analysis shows that adoptive parents tend to attribute their teens' behavior problems to adolescence itself rather than to their adoption (Báñez, 2017).

Despite the dominance of this discourse, a series of studies both internationally and in Spain suggest that the adolescence of adopted children is not inherently problematic and that parents can help their children navigate it successfully (see Berástegui, 2007; Bernedo et al., 2005; Ceballo et al., 2004; Howard et al., 2004; Miller et al., 2000; Rueter et al., 2009; Sánchez-Sandoval and Palacios, 2012).

\section{Essentialism and adoptive kinship}

Essentialist beliefs are a series of ontological assumptions that represent human differences related to personality, phenotypic difference, sex, and other traits. An essentialist approach attributes a fixed and immutable essence to all members of a category. The use of these essentialist beliefs has important consequences both at the individual level, in terms of personal identity and interpersonal relationships (Haslam et al., 2004), and at the social level in the configuration of stereotypes and prejudices toward people of other social groups (Rothbart and Taylor, 1992). Both forms of essentialism are present in the data that I analyze.

According to Bastian and Haslam (2006: 229), the most widespread essentialist belief about human attributes is that of immutability. Along similar lines, Dweck and colleagues have shown that beliefs about the nature of personal characteristics fall into two categories. People with an "entity" mindset consider human attributes to be fixed essences or dispositions (what Bastian and Haslam would call "immutability"). As a result, in situations of conflict they rarely enter dialog, because they do not expect other people to be able to change. On the other hand, people with an

\footnotetext{
${ }^{4}$ http://blogs.ccma.ct/senseficcio.php?itemid $=53435$
} 
Tomasa Báñez Tello, Essentialism in Spanish parents' descriptions of their transnationally adopted teenagers, perifèria 22(2), diciembre 2017

\section{revistes.uab.cat/periferia}

"incremental" mindset consider personal characteristics to be malleable qualities. They draw references that are more specific, conditional, and provisional and tend to talk about their feelings and complaints in order to improve their interpersonal relationships and handle situations of conflict through dialog (Dweck et al., 1993; Kammrath and Dweck, 2006).

Verkuyten (2003) highlights the importance of thinking of essentialism not only as a psychological process but also as a social practice created through discourse. In a similar line, Hirschfeld (1997) shows that when humans' penchant for categorization interacts with the social, economic and political context, essentialism becomes a system for explaining human differences (Hirschfeld, 1997), accentuating them (Rothbart and Taylor, 1992) and valuing other social groups as sub-human (Leyens et al., 2000). In this way, essentialist ideas make it possible to construct, legitimate and reproduce social and cultural categories, presenting them as natural and thus justifying social inequality and discrimination (Stolcke, 2011; Yzerbyt et al., 1997), and denying the existence of personal agency (Herzfeld, 2002).

Essentialism is particularly relevant to adoption because by definition adoption requires an "incremental" rather than an "entity" mindset: adoptive families must believe that family ties can been constructed rather than merely inherited. Yet studies of adoptive kinship show a mix of constructivist and essentialist attitudes. Research from around the world shows that transnational adoptive families use affect, emotion and social interactions to build the family bond. Ironically, at the same time they naturalize this bond (De Graeve and Longman, 2013; De Graeve, 2014; Howell, 2003, 2009; Modell, 1994; Yngvesson, 2002, 2009). Several studies have shown that especially when the child is racially different from the adoptive parents, parents may resort to essentialism, naturalizing the culture of origin of adopted children, as if the cultural identity were a product of biology (Castañeda, 2011; De Graeve, 2014; Howell, 2009; Marre, 2007; Yngvesson, 2010, 2012).

Adoptive families make an effort to include their children in their families, emphasizing destiny and similarities between them and their children. These ties facilitate the child's incorporation into the family and the nation. At the same time, 
Tomasa Báñez Tello, Essentialism in Spanish parents' descriptions of their transnationally adopted teenagers, perifèria 22(2), diciembre 2017

\section{revistes.uab.cat/periferia}

parents may insist on marking their children as nationally, culturally and biologically different (Howell and Marre, 2006).

Looking to Catalonia in particular, we see evidence of essentialism in adoptive families. Marre (2007) points out that when the child is phenotypically different from the adoptive parents, the child's cultural identity is especially likely to be treated as if it were at least partially a product of biology. Participants in Marre's studies have been shown to view not only physical traits but also cultural traits as heritable. For example, one mother adopted a girl in China and another girl in Congo. She chose names that would reflect their supposed inner nature: the girl adopted from China was named Miel (Honey) - to indicate her supposed inner sweetness-and the girl adopted from Congo was named Selva (Forest) - to indicate her supposed inner wildness. Anzil (2012) shows that some parents linked their children's personality traits to the fact that they "had been born in another country, conceived by other people, carriers of another culture, regardless of their age at the time of the adoption" (p. 552). My research differs from the work of these authors' in that I focus specifically on behaviors and attitudes that parents dislike in their children and parents' explanations for them.

\section{Adoption and intensive parenting}

Geinger et al. (2014) have described the values of parenting in today's neoliberal society. These discourses center on social expectations related to children's future as adults capable of engaging as citizens in a globalized and competitive world. This view of parenting legitimizes and contributes to reproducing a model of parenting that makes adult autonomy and productivity the ultimate goal and holds parents responsible for this outcome (Wall, 2010). These ideas are closely related to earlier work by Hays (1996), who identified a phenomenon that she called, "intensive mothering," which emphasizes extreme maternal investment (both emotionally and financially) and the supremacy of expert advice. This is also related to the fact that the family is assigned the social function of "the production of middle-class subjectivity for the adult," which becomes the key indicator to determine parents' social value as "good parents" (Anagnost, 2000: 391). 
Tomasa Báñez Tello, Essentialism in Spanish parents' descriptions of their transnationally adopted teenagers, perifèria 22(2), diciembre 2017

\section{revistes.uab.cat/periferia}

Adoptive parents may be particularly susceptible to the pressures of intensive parenting because they must additionally overcome the perception that their families, because not based in biology, are abnormal (Howell, 2009; Kressierer and Bryant, 1996). This stigmatizing discourse about adoptive kinship is disseminated and reproduced in part through mass media (Potter, 2013) and adoption services (Jociles et al., 2012) and is perceived by adoptive families (Rodríguez-Jaume and Ruiz, 2015). This view requires adoptive parents, especially mothers, to conduct semi-professional parenting that permits them to anticipate problems. Applying the pressures of intensive mothering to transnational adoption places within the family the responsibility to discipline and domesticate difference and to solve any problems that adopted people may face (De Graeve and Longman, 2013).

\section{Method}

This article forms part of a broader, interdisciplinary research project on the familybased and social integration of transnationally adopted children in Spain (Abrines et al., 2012; Báñez, 2017; Barcons-Castel et al., 2011; Barcons-Castel et al., 2012; Barcons-Castel et al., 2014). The Pediatrics Department of a Barcelona hospital ${ }^{5}$ facilitated contact with two samples of families with transnationally adopted children, ranging in age from 6 to 11 and 12 to 18, respectively; this article and Báñez (2017) are preliminary qualitative analyses of the latter group. Parents were interviewed from 2010 to 2012 with the adoptive family version of the Parent Development Interview (Steele, 2003); the interview schedule was translated into Catalan and Spanish and participants conducted the interview in the language of their choice. This semistructured clinical interview designed for quantitative analysis reveals parents' representations of themselves, their children and their relationships with them. These representations are key in parents' reflective functioning, that is, in their ability to be aware of the mental states of their children and take them into account in their relations with them.

5 Transnationally adopted children in Catalonia have regular visits with a pediatrician specialized in adoption; researchers reached out to the parents of all adoptive families receiving such care at the hospital to request that they participate in the study. 
Tomasa Báñez Tello, Essentialism in Spanish parents' descriptions of their transnationally adopted teenagers, perifèria 22(2), diciembre 2017

\section{revistes.uab.cat/periferia}

The interview has been widely used, both in its original version (Slade et al., 1994) and in the version for adoptive parents (Steele et al., 2003). Using this interview schedule with adoptive families has made it possible to evaluate the quality of the parent-child relationship, a key factor in the adaptation and psycho-social development of the adopted child (Simmel et al., 2001). It has also revealed the need to take into account the specificity of the adoptive bond as different from the bond between biological parents and children. Finally, it has deepened the analysis of the influence of social and cultural discourses about parenthood on the family relations of adoptive families (Priddis and Mateljan, 2010).

I examine these interviews from a qualitative point of view (see Priddis and Mateljan, 2010 for a similar approach), focusing on parents' talk about their dislikes regarding their adopted adolescent children. I used thematic analysis (Braun and Clarke, 2006) and discourse analysis (Grbich, 2007) to analyze parents' responses. Through inductive reasoning I devised analytical categories based on parents' responses. The categories enabled me to identify patterns in parents' speech about what they dislike in their children.

The study sample is composed of 24 families, with a total of 32 interviewees (10 men and 22 women). Ages range from 47 to 63 for fathers and 43 to 60 for mothers. All of the parents interviewed had completed higher education and had professional careers. The families resided in the province of Barcelona. The parents, all of whom had European features, consisted of 21 heterosexual couples, one lesbian couple and two single mothers. The children included 11 girls and 13 boys ranging in age between 12 and 18 at the time of the interviews. They came from the following countries: Colombia (8), Ethiopia (4), Ukraine (3), Nicaragua (2), Russia (1), Peru (1), Nepal (1), El Salvador (1), Ecuador (1), Bulgaria (1) and Bolivia (1). The children had phenotypical features indigenous to their countries of origin.

\section{Results}

Most of the parents reported disliking aspects of their children's behavior or attitude. Of course, this outcome is unsurprising, given that some of the interview questions focus explicitly on negative aspects of their children and of parenting. Of more interest to me is how they describe these dislikes and to reflect on what it might 
Tomasa Báñez Tello, Essentialism in Spanish parents' descriptions of their transnationally adopted teenagers, perifèria 22(2), diciembre 2017

\section{revistes.uab.cat/periferia}

imply about their views of parenting and ultimately their parenting practice and their relationship with their children. Note that it is beyond the scope of this study to examine family relationships per se. Rather, I am describing ways of talking about children and using them to generate future research questions.

While most parents reported disliking things about their children, in most cases their complaints were not serious. In fact, the results of other instruments used in the broader study show that these parents expressed satisfaction, both with respect to their children's adaptation process (15 of 24 families valued it as good or very good, seven as good but with difficulties and two as difficult) and with respect to their academic results (nine functioned on grade level comfortably, ten functioned on grade level with difficulty, four functioned below grade level and two had dropped out of school). In this sense, the goal of this article is not to examine the teens' behaviors or compare them with those of the non-adopted population; rather, my analysis focuses on these adoptive parents' descriptions of their children's behaviors and considers possible consequences in terms of childrearing and their relationship with their children. I describe parents' use of a) cultural essentialism and b) personal essentialism.

\section{Cultural essences: Children's places of origin as problematic}

Given the research cited above on cultural essentialism in adoptive families, it is no surprise that we see examples in which parents attribute their children's behavior to their cultures of origin. Some adoptive families reflect in their speech the belief in the deterministic effects of culture on people's character and behavior (Benet-Martínez and Oishi, 2008). Moreover, they compare these supposed traits with values associated with the Catalan national identity of which they form part (see Pujals, 2011).

In the following example, a father uses this kind of logic in describing his daughter, Marian. She is a 17-year-old girl originally from Cameroon who joined the family at age eight.

I: Could you give me a brief description of Marian? 
Tomasa Báñez Tello, Essentialism in Spanish parents' descriptions of their transnationally adopted teenagers, perifèria 22(2), diciembre 2017

\section{revistes.uab.cat/periferia}

F: She has a strong personality. She's a bit reserved, maybe because of how her life has been or maybe it's part of her character. I understand her very well because I'm a bit like her. It's hard for me to express myself $(. .$.$) . Among other$ things, I would define her as an African with a central-European mentality.

I: What do you mean?

F: I mean Catalan from the Vallès, because her memories are from here.

Without making it explicit, this father draws on the supposed essences of (and differences between) Africa, his daughter's place of origin, and of Catalonia. In doing so, he identifies Catalan cultural traits with those of central Europe, which in Spain is identified as the geographic area including Germany and the Low Countries, This mindset is described in the press as "thrifty and petit bourgeois" and characterized by "order, work, talent and seriousness". Because the father's response contrasts Africa with Catalonia, the implicit message is that Africans do not to have these traits.

Other parents link their children's countries of origin to their personality traits more explicitly. The first example comes from the mother of 17 -year-old Maria, a girl from Nepal adopted at age 5 .

I: And do you feel irritated as a mother sometimes?

M: Oh absolutely! When she's hard-headed, yeah. When sometimes she's become defiant for some reason... because Nepalis are very stubborn.

Montserrat, one of Alex's mothers as part of his answer to the question, "Could you briefly describe what Alex is like?":

Alex is (...) an arrogant person... you know those people from the East that are a little arrogant, a little full of themselves. That's how he is. It's genetics; it's true. The French will be one way, the Germans another, right? He's like that...

In these examples, the parents refer to the birthplaces of their children as if their children had common personal characteristics that are innate and inherited, and that defines the identity of all members. In the third example, the mother refers to the character or national identity that is purportedly part of her son's biology ("it's genetics"). 
Tomasa Báñez Tello, Essentialism in Spanish parents' descriptions of their transnationally adopted teenagers, perifèria 22(2), diciembre 2017

\section{revistes.uab.cat/periferia}

Another example comes from Carme, Alex's other mother in response to the question, "How do you think Alex has changed since he arrived here?":

I'm seeing that Alex has developed very little. The possibilities that he had there where it was humanly, socially, I don't know, pretty backward and more primitive... Here on the other hand there are many more possibilities, many things to learn. But he hasn't taken advantage of them. He hasn't taken advantage of them. He's only kept the part that he wants, the part that suits him... He's a very lazy child.

Montserrat, Alex's other mother, coincides with this assessment in her response to the question "What do you like least about Alex?," making reference to his lack of responsibility and effort, especially in his studies:

He leaves everything to the last minute; He doesn't finish things... Like if he has an assignment...he leaves it and if someone does it for him, like a friend for example... he doesn't get too anxious... He's irresponsible...

Although initially this mother seems to recognize the possibility of change in her child ("he has developed") if the context in which he is raised offers opportunities, her answer ends up highlighting that it is an aspect of his personality that has not allowed him to take advantage of the opportunities offered to him in Catalonia ("He's a very lazy child".).

Two additional examples also relate to parents' perception that their children are overly relaxed, slow or lazy. The following exchange occurred with Núria's mother

I: Are there any particular ways in which Núria is different than you and than your spouse?

M: I guess it's that. I see her as being too relaxed... in a lot of things where I think that sometimes she should be more active in how she handles things (...) Maybe it's her character, maybe Indians are a little bit like that. Often I tell her, "Núria, get with it. Because you're going to live here, as far as I know. Unless you decide to go back to India". That level of relaxation that she sometimes has is what bothers me the most. 
Tomasa Báñez Tello, Essentialism in Spanish parents' descriptions of their transnationally adopted teenagers, perifèria 22(2), diciembre 2017

\section{revistes.uab.cat/periferia}

Asked the same question, Albert's mother gives this response:

In how relaxed he is. I always say that he got the genes of those people. "In a minute," but "in a minute" means next year. Because South Americans are like that; they're relaxed about everything.

In all of the above examples, parents link their dislikes to their children's place of origin. We also see the emergence of the recurring theme that many of these teens are "lazy," a trait that contrasts notably with the supposed nature of Catalans to which Marian's father refers implicitly (see above).

\section{Personal essentialism: Children's personal traits as problematic}

In this section, I turn from examples of cultural essentialism to examples of personal essentialism, which occurs when parents attribute their children's behavior to their supposed inner nature or essence. Although adoption and parenting research tends to treat these forms of essentialism separately, I argue that it is worthwhile to examine them together.

Three families mentioned in the last section describe their children as "too relaxed" or "lazy" and relate this trait to their country of origin. This trait appears again in descriptions by two additional families who don't link it explicitly to the question of origins. In total, this supposed personality trait of the children appears in the speech of six parents (from five different families). These parents describe their children as lazy, slackers, irresponsible, idle or nervy (in expecting others to perform work for them). This notion is expressed in the following examples.

Rebecca (age 18) was adopted from Nicaragua at age five. In answer to the question, "What gives you the most pain or difficulty in being a parent?," Rebecca's mother describes her as a lazy person with a poor work ethic. She contrasts this trait with the perseverance that she and her husband have shown in the face of a family business failure that forced both of them to pursue new studies and enter new professions: 
Tomasa Báñez Tello, Essentialism in Spanish parents' descriptions of their transnationally adopted teenagers, perifèria 22(2), diciembre 2017

revistes.uab.cat/periferia

Schedules, waking up, not helping at all at home; both of them are slackers. ${ }^{6}$ And at home, both my husband and I have always been people who do lots of things (...) I hope nothing happens to her (...) To me she doesn't seem ready for the future that awaits her (...) She's not ready in terms of her studies, but I the thing is that I don't see her as ready as a person. She's a slacker; She runs away from work (...) She runs away from everything.

Oriol's mother describes her son in similar fashion:

I: In what ways do you see him as different from you [plural]?

M: In how relaxed he is. If we let him, he would be even more relaxed.

According to these parents, the laziness and lack of effort of their children (represented as part of their personalities and not momentary behaviors) negatively affect their academic results, putting at risk their chances of leading an autonomous adult life.

Another trait parents give is that their children are liars. Carme, one of Alex's mothers, responds as follows to the question, "Could you briefly describe what Alex is like?":

M: The thing is, is that he's a liar. He always lies, always. Gratuitously or not, it doesn't matter. He's a liar by definition...

I: About what kinds of things, for example?

M: About everything, about everything [shrugs shoulders]. Everything (...) This is something since he arrived.

The second example comes from Rebeca's mother, who was asked to choose three adjectives that she felt reflected the relationship between her and her child. Note that the mother is asked to describe the relationship, but instead she gives a description of her daughter:

\footnotetext{
${ }^{6}$ She is referring to Rebeca and Josep, a 16-year-old boy adopted at age three and a half, also from Nicaragua.
} 
Tomasa Báñez Tello, Essentialism in Spanish parents' descriptions of their transnationally adopted teenagers, perifèria 22(2), diciembre 2017

\section{revistes.uab.cat/periferia}

This gives you a sense of mistrust (...) She's a real liar (...) and this makes you feel really bad, you know (...) It's really difficult for me to live like this; What can I say (...) Just my luck!

Both parents describe their children's lies as a consequence of an immutable and innate personality trait ("He's/She's a liar") that has no hope of improvement. In particular, the second example reveals the denial of agency in childrearing: "Just my luck!". Here, the daughter's undesirable behaviors are not the result of something the mother did, but rather, "just my [bad] luck"-the outcome of essences "lottery". This interpretation is consistent with the essentialist explanation of personal traits as immutable. The emphasis on these particular traits (lazy, liar) contrasts sharply with neoliberal discourse about ideal traits; it is therefore not surprising that these traits upset the parents and appear repeatedly in parents' descriptions of their dislikes.

\section{Discussion and conclusions}

As we have seen, when describing things they dislike about their children, some parents give essentialists descriptions of their children, either in terms of their cultural origins or their inherent traits, or both. Interestingly, it seems that the essentialist discourse that I encountered may in fact fill a similar function to the abandonment discourse that San Román (2013) describes. Essentialist discourse, like abandonment discourse, may allow parents to place the source of their children's perceived problems outside of their control, an option that may be particularly attractive given the pressures of neoliberal parenting described above. This recalls a statement by one study father about his son Paul: "There are times when it's difficult to manage him". The father implies that it is parents' responsibility to "manage" their children. Attributing behaviors to their children's personal traits and culture of origin excuses parents from responsibility for the outcome of their parenting efforts.

Despite the small sample size, my preliminary results point to the potential benefits of studying adoption in general-and transnational adoption in particular-in the context of a larger analysis of essentialism. Future studies should complement the self-report data that I have analyzed here with participant observation of families centered on speech within the family and on childrearing practices to examine the link between essentialism and family life. Moreover, a larger sample could help to 
Tomasa Báñez Tello, Essentialism in Spanish parents' descriptions of their transnationally adopted teenagers, perifèria 22(2), diciembre 2017

\section{revistes.uab.cat/periferia}

tease out to what extent the gravity of a child's problems, gender, country of origin, phenotype, family form, or other variables, affect the likelihood that parents will use essentialist explanations.

Future study design should also include the comparison of adoptive and non-adoptive families. The current analysis generates the prediction that adoptive families would be more likely to voice essentialist discourses than non-adoptive families. In part, this is because cultural essentialism is at the disposal of adoptive parents but not of biological parents; the question is whether the availability of the discourse of cultural essentialism conditions adoptive parents toward the use of personal essentialism as well. Adoptive parents also may be more likely to resort to essentialist explanations because essentialism protects adoptive parents from all "blame" for their children's behaviors, since neither the genetic nor the cultural "essences" originate with them. The discourse of essentialism is likely less useful to non-adoptive parents, since they share genetic and cultural origins with their children. An empirical comparison of adoptive and biological families on the question of essentialism is needed to test these hypotheses.

The question matters, because various studies have noted the consequences of essentialist beliefs on identity, interpersonal relationships and conflict management strategies (Dweck et al., 1993; Kammrath and Dweck, 2006). Likewise, studies have shown that parents' interpretations of their children's behaviors affect not only the parents' satisfaction and self-esteem (Johnston, 1996), but also their parenting styles and strategies (Jones and Davis 1965; Miller, 1995) and their approaches to discipline (Dix and Lochman, 1990). Parents holding these beliefs may not expect their children to (be able to) change. And therefore in situations of tension, which are common in many families with adolescent children, they may be less likely to offer dialog and negotiation, a tendency that may exacerbate problems. Moreover, the parents' use of essentialist beliefs about people and cultures may have important consequences for the identity of their children (see San Román and Marre, 2013).

My analysis shows that most adoptive parents interviewed express dislikes about their teenage children and many give essentialist descriptions of the things they dislike about their children. Adoptive parents' use of essentialist discourses is 
Tomasa Báñez Tello, Essentialism in Spanish parents' descriptions of their transnationally adopted teenagers, perifèria 22(2), diciembre 2017

\section{revistes.uab.cat/periferia}

particularly troubling because adoption-and especially transracial adoption-in theory is based on the denial of the importance of human differences and/or their integration into a model of family in which kinship ties are constructed not on a biological base or essence, but rather on family interactions. That essentialism appears among adoptive families speaks to the tenacity of the phenomenon and bears further investigation.

The results of this analysis can guide family and professional practices and public policies about adoption. Clinicians and educators should keep in mind parents' interpretations of their children's behavior and be sensitive to the possibility of essentialism and its potentially negative consequences. While thinking of their children's problems as "just my luck" may help them manage social pressures to produce model citizens, this discourse may in fact limit their ability to guide their children successfully into adulthood. Both of these issues should be studied empirically in future research. Regardless of the neoliberal discourse about their roles, parents ultimately cannot control the reactions and behaviors of their children. However, adoptive (and other) parents should receive support to demonstrate to them that through their own agency and through positive childrearing strategies, ${ }^{7}$ they can contribute to (though not control) the development and wellbeing of their children.

\section{Acknowledgments}

Susan Frekko provided feedback on some versions of this article and translated it from Spanish into English. I am grateful for the opportunity to work with these data, which are part of the database of the AFIN research group of the Autonomous University of Barcelona. In particular, I thank Neus Abrines and Natàlia Barcons, who developed the original project and collected the data, and PI Diana Marre for her invitation to participate in the analysis phase and for her support and encouragement

7 For example, this vision of parenting-which explicitly rejects essentialism and labeling-is presented in these two guides for parents widely distributed in Spain: Faber and Mazlish (1997); Nelsen (2002). 
Tomasa Báñez Tello, Essentialism in Spanish parents' descriptions of their transnationally adopted teenagers, perifèria 22(2), diciembre 2017

\section{revistes.uab.cat/periferia}

throughout the writing process. Finally, I thank all study participants for their availability and generosity.

\section{Funding acknowledgment}

This article was developed under the auspices of the R\&D project CSO2012-39593C02-01 "Adoptions and Fosterages in Spain: Tracing Challenges, Opportunities and Problems in the Social and Family Lives of Children and Adolescents," financed by Spain's Ministry of Economy and Competitiveness.

\section{Bibliography}

Abrines, N., Barcons, N., \& Marre, D. (2012). ADHD-like Symptoms and Attachment in Internationally Adopted Children. Attachment and Human Development,14(4),405-423. ttp://dx.doi.org/10.1080/14616734.2012.691656

Anagnost, A. (2000). Scenes of Misrecognition: Maternal Citizenship in the Age of Transnational Adoption. Positions-East Asia Cultures Critique,8(2),389-421. https://doi.org/10.1215/10679847-8-2-389.

Anzil, V. (2012). "Si yo cerrara los ojos y la tuviera delante, o sea, sin mirarla... sería una niña totalmente española, catalana, de aquí": Representaciones, identidades y filiaciones en la adopción internacional en Cataluña. PhD Thesis, Universitat Rovira i Virgili, Tarragona, Spain.

Anzil, V. (2013). Adopting "Imaginaries": International Adoption in the Spanish Press. $\begin{array}{llll}\text { Adoption } \quad \& \quad \text { Fostering,37(1), } & \text { 71-82. }\end{array}$ https://doi.org/10.1177/0308575913477071

Báñez, T. (2017) "All teenagers have problems, whether they're adopted or not": Discourses on adolescence and adoption among parents of transnationally adopted teens. Qualitative Social Work, Volume: 16 issue: 3, 394-410. https://doi.org/10.1177/1473325015617234

Barcons, N., Abrines, N., \& Brun, C. (2012). Social Relationships in Children from Intercountry Adoption. Children and Youth Services Review,34(5),955-961. https://doi.org/10.1016/j.childyouth.2012.01.028 
Tomasa Báñez Tello, Essentialism in Spanish parents' descriptions of their transnationally adopted teenagers, perifèria 22(2), diciembre 2017

\section{revistes.uab.cat/periferia}

Barcons-Castel, N., Fornieles-Deu, A., \& Costas-Moragas, C. (2011). International Adoption: Assessment of Adaptive and Maladaptive Behavior of Adopted Minors in Spain. The Spanish Journal of Psychology,14(1),123-132. https://doi.org/10.5209/rev_sjop.2011.v14.n1.10

Bastian, B., \& Haslam, N. (2006). Psychological Essentialism and Stereotype Endorsement. Journal of Experimental Social Psychology,42(2),228-235. https://doi.org/10.1016/j.jesp.2005.03.003

Benet-Martínez, V., \& Oishi, S. (2008). Culture and Personality. In Handbook of Personality: Theory and Research (pp.542-567). New York: The Guilford Press.

Berástegui, A. (2007). La adaptación familiar en adopción internacional: un proceso de estrés y afrontamiento. Anuario de Psicología,38(2),209-224.

Bernedo Muñoz, I., Fuentes Rebollo, M. J., \& Fernández Molina, M. (2005). Percepción del grado de conflicto en familias adoptivas y no adoptivas. Psicothema,17(3),370-374.

Braun, V., \& Clarke, V. (2006). Using Thematic Analysis in Psychology. Qualitative Research in Psychology,3(2),77-101. https://doi.org/10.1191/1478088706qp063oa

Castañeda, C. (2011). Adopting Technologies: Producing Race in Trans-National Adoption. The Scholar and Feminist Online,9(1-2),1-9.

Ceballo, R., Lansford J., Abbey, A., \& Stewart, A. (2004). Gaining Child: Comparing the Experiences of Biological Parents, Adoptive Parents and Stepparents. Family Relations,53,38-48. https://doi.org/10.1111/j.1741-3729.2004.00007.x

De Graeve, K. (2014). Geographies of Migration and Relatedness: Transmigrancy in Open Transnational Adoptive Parenting. Social and Cultural Geography,16(5), 522-535. https://doi.org/10.1080/14649365.2014.958521

De Graeve, K., \& Longman, C. (2013). Intensive Mothering of Ethiopian Adoptive Children in Flanders, Belgium. In Parenting in Global Perspective: Negotiating Ideologies of Kinship, Self and Politics (pp.136-50). New York: Routledge. https://doi.org/10.4324/9780203103906 
Tomasa Báñez Tello, Essentialism in Spanish parents' descriptions of their transnationally adopted teenagers, perifèria 22(2), diciembre 2017

\section{revistes.uab.cat/periferia}

Dix, T., \& Grusec, J. E. (1985). Parental Attributional Processes in The Socialization of Children. In Parental Belief Systems: The Psychological Consequences for Children (pp. 201-223). Hillside, NJ: Lawrence Erlbaum.

Dix, T., \& Lochman, J. E. (1990). Social Cognition and Negative Reactions to Children: A Comparison of Mothers of Aggressive and Nonaggressive Boys. Journal of Social and Clinical Psychology,9,418-438. https://doi.org/10.1521/jscp.1990.9.4.418

Dweck, C. S., Yi Hong, Y., \& Yue Chiu, C. (1993). Implicit Theories Individual Differences in the Likelihood and Meaning of Dispositional Inference. Personality and Social Psychology Bulletin, 19(5), 644-656. https://doi.org/10.1177/0146167293195015

Faber, A., Mazlish, E. (1997). Cómo hablar para que sus hijos le escuchen y cómo escuchar para que sus hijos le hablen. Barcelona: Medici.

Geinger, F., Vandenbroeck, M., \& Roets, G. (2014). Parenting as a Performance: Parents as Consumers and (De)Constructors of Mythic Parenting and Childhood Ideals. Childhood,21(4),488-501. https://doi.org/10.1177/0907568213496657

Grbich, C. (2007). Qualitative data analysis: An introduction. London: Sage.

Hays, S. (1996). The cultural contradictions of motherhood. New Haven, CT: Yale University Press.

Herzfeld, M. (2002). Essentialism. In Encyclopedia of Social and Cultural Anthropology (pp.188-190). London: Routledge.

Hirschfeld, L. (1997). The Conceptual Politics of Race: Lessons from our Children. Ethos,25,63-92. https://doi.org/10.1525/eth.1997.25.1.63

Howard, J. A., Livingston Smith, S., \& Ryan, S. D. (2004). A Comparative Study of Child Welfare Adoptions with Other Types of Adopted Children and Birth Children. Adoption Quarterly,7,1-30. https://doi.org/10.1300/j145v07n03_01

Howell, S. (2003). Kinning: The Creation of Life Trajectories in Transnational Adoptive Families. Journal of the Royal Anthropological Institute,9:465-484. https://doi.org/10.1111/1467-9655.00159 
Tomasa Báñez Tello, Essentialism in Spanish parents' descriptions of their transnationally adopted teenagers, perifèria 22(2), diciembre 2017

\section{revistes.uab.cat/periferia}

Howell, S. (2009). Adoption of the Unrelated Child: Some Challenges to the Anthropological Study of Kinship. Annual Review of Anthropology,38,149-166. https://doi.org/10.1146/annurev.anthro.37.081407.085115

Howell, S., \& Marre, D. (2006). To Kin a Transnationally Adopted Child in Norway and Spain: The Achievement of Resemblances and Belonging. Ethnos,71(3),293316. https://doi.org/10.1080/00141840600902679

Hoksbergen, R. (1991). Generaciones de padres adoptivos: cambios en las motivaciones para la adopción. Infancia y Sociedad, 12, 25-48.

Hübinette, T., \& Andersson, M. (2012). Between Colourblindness and Ethnicisation: Transnational Adoptees and Race in a Swedish Context. Adoption \& Fostering,36(3-4),97-103. https://doi.org/10.1177/030857591203600310

Institut d'estadística de Catalunya (IDESCAT) (2016). Adopció internacional. Per país de procedència. http://www.idescat.cat/economia/inec?tc=3andid=d106 [Retrieved 06-01-2016].

Instituto Nacional de Estadística (INE) (2016). Medidas de protección a la infancia y adopciones.

http://www.msssi.gob.es/ssi/familiasInfancia/adopciones/estadisticas.htm [Retrieved 06-01-2016].

Jociles, M.I., Rivas, A. M., \& Poveda, D. (2012). Las representaciones expertas sobre las solicitudes individuales en los procesos de adopción. Revista de Dialectología y Tradiciones Populares,67(2),535-558. https://doi.org/10.3989/rdtp.2012.21

Johnston, C. (1996). Parent Characteristics and Parent-Child Interactions in Families of Nonproblem Children and ADHD Children with Higher and Lower Levels of Oppositional-Defiant Behavior. Journal of Abnormal Child Psychology,24,85104. https://doi.org/10.1007/bf01448375

Jones, E., \& Davis, K. (1965). From Acts To Dispositions: The Attribution Process in Person Perception. In Advances in Experimental Social Psychology (pp. 219266). New York: Academic Press. 
Tomasa Báñez Tello, Essentialism in Spanish parents' descriptions of their transnationally adopted teenagers, perifèria 22(2), diciembre 2017

revistes.uab.cat/periferia

Kammrath, L. K., \& Dweck, C. (2006). Voicing Conflict: Preferred Conflict Strategies Among Incremental and Entity Theorists. Personality and Social Psychology Bulletin,32(11),1497-1508. https://doi.org/10.1177/0146167206291476

Kressierer, D. K., \& Bryant, C. D. (1996). Adoption as Deviance: Socially Constructed Parent-Child Kinship as a Stigmatized and Legally Burdened Relationship. Deviant Behavior,17(4),391-415. https://doi.org/10.1080/01639625.1996.9968037

Leyens, J. P., Paladino, P. M., \& Rodriguez-Torres, R. (2000). The Emotional Side of Prejudice: The Attribution of Secondary Emotions to Ingroups and Outgroups. Personality and Social Psychology Review,4,186-197. https://doi.org/10.1207/s15327957pspr0402_06

Lind, J. (2012). "As Swedish as Anybody Else" Or "Swedish, But Also Something Else"? Discourses on Transnational Adoptee Identities in Sweden. Adoption \& Fostering,36(3-4),85-96. https://doi.org/10.1177/030857591203600309

Marre, D. (2007). "I want her to learn her language and maintain her culture": Transnational adoptive families' views of "cultural origins". In Race, ethnicity and nation: Perspectives from kinship and genetics (pp.73-94). New York and Oxford: Berghahn Books.

Miller, B. D., Fan X., Christensen, M., Grotevant, H. D. \& Dulmen, M. V. (2000). Comparisons of Adopted and Nonadopted Adolescents in a Large, NationallyRepresentative Sample. Child Development,71,1458-1473. https://doi.org/10.1111/1467-8624.00239

Miller, S. (1995). Parents' Attributions for Their Children's Behavior. Child Development,66,1557-1584. https://doi.org/10.2307/1131897

Modell, J. S. (2002). A sealed and secret kinship: The culture of policies and practices in American adoption. London and New York: Berghahn Books.

Nelsen, J. (2002). Disciplina positiva: consejos que invitan a la cooperación entre padres e hijos basados en la dignidad y el respeto. Barcelona: Ediciones Oniro, SA. 
Tomasa Báñez Tello, Essentialism in Spanish parents' descriptions of their transnationally adopted teenagers, perifèria 22(2), diciembre 2017

revistes.uab.cat/periferia

Potter, J. E. (2013) Adopting Commodities: A Burkean Cluster Analysis of Adoption Rhetoric. Adoption Quarterly,16(2),108-127. https://doi.org/10.1080/10926755.2013.787573

Priddis, L., \& Mateljan, L. (2010). Maternal Experiences of Inter-Country Adoptions: Implications and Challenges. Australian Journal of Adoption,2(2),1-27.

Pujals, J. M. (2011). Valors propis de la nostra cultura. VIA16 Revista del Centre d'Estudis Jordi Pujol: 29-38.

Rodríguez-Jaume, M. J., \& Ruiz, D. J. (2015). Estigma social y adopción internacional en España: ¿Es la familia adoptiva un modelo familiar menos "auténtico" que los basados en lazos biológicos? Papers: Revista de Sociología,100(2),211-236. https://doi.org/10.5565/rev/papers.2070

Rothbart, M., \& Taylor, M. (1992). Category Labels and Social Reality: Do We View Social Categories as Natural Kinds? In Language and Social Cognition (pp.1136). London: Sage.

Rueter, M. E., Keyes, M. A., Iacono, W. G. at al. (2009). Family interactions in Adoptive Compared to Nonadoptive Families. Journal of Family Psychology,23(1),58-66. https://doi.org/10.1037/a0014091

San Román, B. (2013). De los "hijos del corazón" a los "niños abandonados": construcción de "los orígenes" en la adopción en España. Papeles del Psicólogo,34(1),2-10.

San Román, B., \& Marre, D. (2013). De "chocolatinas" y "princesas de ojos rasgados": sobre la diferencia "fisonómica" en la adopción transracial en España. In Maternidades, procreación y crianza en transformación (pp.123-142). Barcelona: Bellaterra,

Sánchez-Sandoval, M. J., \& Palacios, J. (2012). Stress in Adoptive Parents of Adolescents. Children and Youth Services Review,34(7),1283-1289. https://doi.org/10.1016/j.childyouth.2012.03.002

Selman, P. (2009). The Movement of Children for International Adoption: Developments and Trends in Receiving States and States Of Origin, 1998-2004. 
Tomasa Báñez Tello, Essentialism in Spanish parents' descriptions of their transnationally adopted teenagers, perifèria 22(2), diciembre 2017

\section{revistes.uab.cat/periferia}

In International Adoption: Global Inequalities and the Circulation of Children (pp. 32-51). New York: New York University Press.

Selman, P. (2012). Tendencias globales en adopción internacional: ¿En el "interés superior de la infancia"? Scripta Nova: revista electrónica de geografía y ciencias sociales, 16(395),21. http://www.ub.edu/geocrit/sn/sn-395/sn-395-21.htm

Simmel, C., Brooks, D., Barth, R. P., \& Hinshaw, S. P. (2001). Externalizing Symptomology among Adoptive Youth: Prevalence and Preadoption Risk Factors. Journal of Abnormal Child Psychology,29(1),57-69. https://doi.org/10.1097/00004703-200110000-00014

Slade, A., Aber, J. L., \& Fiorello, J. (1994). Parent development interview coding system. New York: City University of New York.

Snyder, J., Cramer, A., Afrank, J. (2005). The Contributions of Ineffective Discipline and Parental Hostile Attributions of Child Misbehavior to the Development of Conduct Problems at Home and School. Developmental Psychology,41(1),30. https://doi.org/10.1037/0012-1649.41.1.30

Steele, M. (2003, December). A Longitudinal Study of Previously Maltreated Children: Attachment Representations and Adoption. Paper presented at the conference Developmental Science and Psychoanalysis: Integration and Innovation, Yale Child Study Center, New Haven, CT.

Stolcke, V. (2011). ¿Naturaleza o cultura? Un debate necesario. Quaderns de I'Institut Català d'Antropologia,27,5-10.

Verkuyten, M. (2003). Discourses about Ethnic group (de-)Essentialism: Oppressive and Progressive Aspects. British Journal of Social Psychology,42, 371-391. https://doi.org/10.1348/014466603322438215

Wall, G. (2010). Mothers' Experiences with Intensive Parenting and Brain Development Discourse. Women's Studies International Forum,33(3),253-263. https://doi.org/10.1016/j.wsif.2010.02.019

Yngvesson, B. (2002). Placing the "Gift Child" in Transnational Adoption. Law and Society Review,36,227-256. https://doi.org/10.2307/1512176 
Tomasa Báñez Tello, Essentialism in Spanish parents' descriptions of their transnationally adopted teenagers, perifèria 22(2), diciembre 2017

revistes.uab.cat/periferia

Yngvesson, B. (2009). Refiguring Kinship in the Space of Adoption. In International Adoption: Global Inequalities and the Circulation of Children (pp.103-118). New York: New York University Press.

Yngvesson, B. (2010). Belonging in an adopted world: Race, identity, and transnational Adoption. Chicago: University of Chicago Press.

Yngvesson, B. (2012). Colocando al niño/a-regalo en la adopción internacional. Scripta Nova: revista electrónica de geografía y ciencias sociales,16(395).

Yzerbyt, V., Rocher, S., Schadron, G. (1997). Stereotypes as Explanations: A Subjective Essentialistic View of Group Perception. In The Social Psychology Of Stereotyping And Group Life (pp. 20-50). Malden, MA: Blackwell. 